\title{
CLINICAL CORRELATION OF AMAVATA WITH ARTHROPATHIES
}

\begin{abstract}
NEERA SAINI ${ }^{1}$, SINGH NK ${ }^{2}$, BYADGI PS ${ }^{1 *}$
${ }^{1}$ Department of Vikriti Vigyan, Faculty of Ayurveda, Institute of Medical Sciences, Banaras Hindu University, Varanasi, Uttar Pradesh, India. ${ }^{2}$ Department of Medicine, Institute of Medical Sciences, Banaras Hindu University, Varanasi, Uttar Pradesh, India. Email: psbyadgi@gmail.com

Received: 23 January 2017, Revised and Accepted: 01 May 2017
\end{abstract}

ABSTRACT

Objective: The objective of the study was to evaluate the disease Amavata with current understanding of International Classification of Diseases (ICD) 2010

Methods: For the present clinical study, a total of 100 patients were selected. Selection of the patients was done using subjective criteria (mentioned in Ayurvedic samhitas) to diagnose Amavata. Moreover, these patients were classified into three stages according to duration ( 6 months, more than 6 months, more than 1 year) of disease. Laboratory investigations were advised such as hematological parameters and collagen profile.

Results: A total of 100 cases of Amavata were divided into two groups based on ICD classification 2010.86 cases of Amavata patients were diagnosed as rheumatoid arthritis including all the three stages. 14 cases of Amavata were diagnosed as systemic lupus erythematosus, reactive arthritis, and ankylosing spondylitis including all the three stages.

Conclusion: Amavata is a syndrome may be correlated to arthropathies described under ICD classification 2010.

Keywords: Amavata, Rheumatoid arthritis, Systemic lupus erythematosus, Reactive arthritis, Ankylosing spondylitis.

(C) 2017 The Authors. Published by Innovare Academic Sciences Pvt Ltd. This is an open access article under the CC BY license (http://creativecommons. org/licenses/by/4. 0/) DOI: http://dx.doi.org/10.22159/ajpcr.2017.v10i8.17251

\section{INTRODUCTION}

Due to consumption of Vata, Pitta, and Kapha aggravating factors [1] and substances which favors the formation of Ama causes sluggish functions of Agni and develops Ama inside the gastrointestinal tract [2] and enters the Trika region (joints where more than two bones unite to form an anatomical structure called Trika Sandhi) and Sandhi pradesha (various joints of body) causing Stabdhata (stiffness) in joints leading to genesis of Amavata [3]. Amavata is considered as rheumatoid arthritis (RA) only since a long period but other diseases mentioned under arthropathies also fulfills the diagnostic criteria of Amavata. The aim of this study is to evaluate the disease Amavata with current understanding of International Classification of Diseases 2010

\section{METHODS}

\section{Study design}

Selection of the patients was done using subjective criteria mentioned for the clinical diagnosis of Amavata, and all the selected patients were advised to undergo ancillary investigation to diagnose the diseases from current perspectives.

On the basis of duration of disease all the patients were divided into three stages.

- Stage 1: Duration <6 months

- Stage 2: Duration more than 6 months but $<1$ year

- Stage 3: Duration more than 1 year.

Inclusion criteria

a. Registered patients belonged to age group $>15$ years

b. Patients who fulfilled the criteria of diagnostic features of Amavata (Samanya Lakshana and Pravriddha Lakshana).

\section{Exclusion criteria}

a. Patients with age below 15 years

b. Patients, who did not fulfill Amavata diagnostic criteria.
Selection of the patients was done from September 2012 to March 2013 from the Vikriti Vigyan and Rheumatology OPDs.

\section{Ethical committee}

Ethical clearance was taken from the institutional ethics committee.

\section{Diagnostic criteria of Samanya Lakshana of Amavata [4]}

Daurbalya (weakness), Gauravam hridayasya (heaviness in precordial region), Trika Sandhi Praveshakau Stabdham (stiffness in joints), Angamarda (bodyache), Aruchi (anorexia), Trishna (thirst), Alasya (lethargy), Gauravam (heaviness), Jvara (fever), Apaka (indigestion), and Shunata Anganam (swelling).

\section{Specific or Pravriddha Lakshana of Amavata [3]}

Hasta Padashiro Gulpha Trika Janu Uru Sandhi Sa Rujam Shotham (pain and swelling in hand, feet, ankle, knee, hip, and spinal joints), Rujyate Atyartham (excruciating pain), Vyaviddha Iva Vrishcika (pain like scorpion sting), Agnidaurbalya (hindered digestive mechanism), Praseka (excessive salivation), Aruchi (anorexia), Gauravam (heaviness), Utsahahani (lack of enthusiasm), Vairasya (altered taste of mouth cavity), Daham (burning sensation), Bahumutratam (excessive urination), Kukshau Kathinatam Shulam (hardness and pain in abdomen), Nidraviparyaya (disturbed sleep), Trit (thirst), Chardi (nausea), Bhrama (fainting), Murccha (unconsciousness), Hrid Graha (stiffness in pericordium), Vidvibaddhatam (constipation), Jadya (stiffness), Antrakujanam (intestinal gurgling), and Anaha (distension in abdomen).

Investigation profile

- Hematological parameters - Complete blood count, erythrocyte sedimentation rate.

- Collagen profile including C-reactive protein, rheumatoid factor, anticyclic citrullinated peptide (CCP), antinuclear antibody, antidouble stranded DNA tests, and human leukocyte antigen (HLA) B27. 
Statistical analysis

Chi-squared test and $\mathrm{Z}$ test were used to compare the incidence of symptoms between two groups.

Indication of significant or non-significant

When the result is significant, it means there is significant difference between groups for an individual symptom. That symptom may have high frequency in any group. If the result is non-significant it means the possibility of a particular symptom for its presence or absence is same in all groups.

\section{OBSERVATION AND RESULTS}

Stage 1: Total 15 cases of Amavata patients were belonged to $<6$ months duration.

Stage 2: Total 10 cases of Amavata patients were belonged to more than 6 months duration.

Stage 3: Total 75 cases of Amavata patients were belonged to more than 1 year duration.

A total of 100 cases of Amavata were subjected to complete blood count, erythrocyte sedimentation rate, and collagen profile. On the basis of investigation report Amavata patients divided into two groups.

Group A $(n=86)$ : RA. 13 cases of Stage 1, 9 of Stage 2 and 64 of Stage 3 .

Group B (n=14): Comprises systemic lupus erythematosus (SLE), reactive arthritis (Re.A), and ankylosing spondylitis (AS), and these were further subdivided into subgroups.

Table 1: Age wise distribution of the Amavata patients $(n=100)$

\begin{tabular}{lll}
\hline S. No. & Age group (years) & Total (\%) \\
\hline 1 & $15-24$ & $4(4)$ \\
2 & $25-34$ & $36(36)$ \\
3 & $35-44$ & $28(28)$ \\
4 & $45-54$ & $24(24)$ \\
5 & $55-64$ & $8(8)$ \\
\hline
\end{tabular}

This group was further divided into three subgroups based on their number.

Subgroup $1(n=6)$ : SLE divided as 1 of Stage 2, 5 of Stage 3.

Subgroup $2(n=5)$ : Re.A divided as 1 of Stage 1 , and 4 of Stage 3.

Subgroup $3(n=3)$ : AS divided as 1 of Stage 1 and 2 of Stage 3.

Due to less number of cases in all three subgroups of Group 2, statistical analysis was analyzed as Group 2 in different stages.

$36 \%$ cases of Amavata were observed in the age group of 25-34 years (Table 1).

$84 \%$ patients of RA were females. $100 \%$ patients of SLE were females (Table 2).

\section{Assessment of Samanya Lakshana of Amavata}

I. In Stage $1(\mathrm{n}=15)$

- Group A (n=13) - Trika Sandhi Pravehakau Stabdham, Jvara, Apaka and Shunata Anganama were present in all cases (100\%) followed by Daurbalya and Alasya (92\%).

- Group B (n=2):

Subgroup $1(\mathrm{n}=0)$ has no case.

Subgroup $2(\mathrm{n}=1)$ Patient has all symptoms except Trishna and Aruchi.

Subgroup $3(\mathrm{n}=1)$ Patient has all symptoms except Gauravam Hrdayasya, Trishna and Jvara.

II. In Stage $2(\mathrm{n}=10)$

- Group A (n=9) - maximum symptoms were present in all cases, i.e., $100 \%)$.

- $\quad$ Group B $(\mathrm{n}=1)$ :

Subgroup $1(\mathrm{n}=1)$ : Patient has all symptoms except Trishna and Jvara.

Subgroup 2 and Subgroup $3(\mathrm{n}=0)$ : No cases.

III. In Stage $3, \mathrm{n}=75$ showing in Table 3.

\section{Group A ( $n=64)$}

Angamarda was present in all cases, i.e., $100 \%$, followed by followed by Daurbalya, Trika sandhi praveshakau stabdham and Shunata anganama (97\%), Apaka (94\%), Alasya (92\%), Aruchi (73\%), Jvara (64\%), Gauravam (63\%), Trishna (41\%), and Gauravam hridayasya (25\%).

Table 2: Sex wise distribution in the two groups of Amavata $(n=100)$

\begin{tabular}{lllll}
\hline Sex & Group 1 (n=86) RA (\%) & Group 2 (n=14) & & \\
\cline { 3 - 5 } & & Subgroup 1 & Subgroup 2 & \multicolumn{1}{c}{ Subgroup 3 } \\
\cline { 3 - 5 } & & SLE (n=6) (\%) & Re.A (n=5) (\%) & A.S (n=3) (\%) \\
\hline Male & $14(16)$ & $0(0)$ & $2(40)$ & $2(66)$ \\
Female & $72(84)$ & $6(100)$ & $3(60)$ & $1(33)$ \\
\hline
\end{tabular}

SLE: Systemic lupus erythematosus, Re.A: Reactive arthritis, AS: Ankylosing spondylitis, RA: Rheumatoid arthritis

Table 3: Assessment of Samanya Lakshana of Amavata in Stage $3(n=75)$ and comparison of symptoms between two groups

\begin{tabular}{|c|c|c|c|c|c|c|}
\hline \multirow[t]{2}{*}{ S. No. } & \multirow[t]{2}{*}{ Symptoms } & \multirow{2}{*}{$\begin{array}{l}\text { Group A }(n=64) \\
\text { RA n=64 (\%) }\end{array}$} & \multicolumn{3}{|l|}{ Group B $(n=11)$} & \multirow[t]{2}{*}{$Z$ value and $p$ value } \\
\hline & & & $\begin{array}{l}\text { Subgroup } 1 \\
\text { (SLE) } n=5(\%)\end{array}$ & $\begin{array}{l}\text { Subgroup } 2 \\
\text { (Re.A) } n=4(\%)\end{array}$ & $\begin{array}{l}\text { Subgroup } 3 \\
\text { (AS) } n=2(\%)\end{array}$ & \\
\hline 1 & Daurbalya & $62(97)$ & $5(100)$ & $4(100)$ & $2(100)$ & $\mathrm{Z}=1.40, \mathrm{p}>0.05$ \\
\hline 2 & Gauravam Hrdayasya & $16(25)$ & $3(60)$ & $1(25)$ & $2(100)$ & $\mathrm{Z}=1.88, \mathrm{p}>0.05$ \\
\hline 3 & Trika Sandhi Praveshakau Stabdham & $62(97)$ & $5(100)$ & $4(100)$ & $2(100)$ & $Z=1.40, p>0.05$ \\
\hline 4 & Angamarda & $64(100)$ & $5(100)$ & $4(100)$ & $2(100)$ & $\mathrm{Z}=0, \mathrm{p}>0.05$ \\
\hline 6 & Trishna & $26(41)$ & $4(80)$ & $3(75)$ & $1(50)$ & $\mathrm{Z}=2.17, \mathrm{p}<0.05$ \\
\hline 7 & Alasya & $59(92)$ & $5(100)$ & $4(100)$ & $2(100)$ & $\mathrm{Z}=2.35, \mathrm{p}<0.05$ \\
\hline 8 & Gauravam & $40(63)$ & $5(100)$ & $4(100)$ & $1(50)$ & $\mathrm{Z}=2.6, \mathrm{p}<0.01$ \\
\hline 9 & Jvara & $41(64)$ & $5(100)$ & $4(100)$ & $2(100)$ & $\mathrm{Z}=6, \mathrm{p}<0.01$ \\
\hline 10 & Apaka & $60(94)$ & $5(100)$ & $4(100)$ & $2(100)$ & $\mathrm{Z}=2.02, \mathrm{p}<0.05$ \\
\hline 11 & Shunata Anganama & $62(97)$ & $5(100)$ & $4(100)$ & $2(100)$ & $\mathrm{Z}=1.40, \mathrm{p}>0.05$ \\
\hline
\end{tabular}


Group B (n=11)

Subgroup $1(n=5)$

Most of symptoms were present in all cases, i.e., 100\%.

Subgroup $2(n=4)$

Most of symptoms were present in all cases, i.e., 100\%.

Subgroup $3(n=2)$

Most of symptoms were present in all cases, i.e., 100\%.

Comparison between Group 1 and Group 2

Due to very less registered cases in Stage 1 and 2, "Z" test could not be applied due to which comparison could not be done.

But in Stage 3, "Z" is applied and on comparison - Table 3 shows that between the all symptoms of Amavata as Alasya, Aruchi, Trishna, Gauravam, Jvara, and Apaka show significant result.

\section{Assessment of Pravriddha Amavata Lakshana of Amavata}

I. In Stage $1(\mathrm{n}=15)$

- Group A (n=13): Hasta Padashiro Gulpha Trika Janu Uru Sandhishau Sarujam Shotham, Rujyate Atyartham, Vyaviddha Iva Vrishcika, Agnidaurbalya, Daham and Jadya were present in all cases i.e., $(100 \%)$.

- Group B $(\mathrm{n}=2)$ :

Subgroup $1(\mathrm{n}=0)$ : 0 patients were belonged to this group

Subgroup 2 ( $n=1$ ): Most of symptoms were present, i.e., 100\%.

Subgroup $3(\mathrm{n}=1)$ : Most of symptoms were present, i.e., $100 \%$.

II. In Stage $2(\mathrm{n}=10)$

- Group A (n=9): Agnidaurbalya, Gauravam, Utsahahani, Bahumutratam, and Hrid Graha were present in all cases, i.e., 100\%, followed by Hasta Padashiro Gulpha Trika Janu Uru Sandhishau Sarujam Shotham and Rujyate Atyartham (96\%).

- Group B (n=1)

Subgroup $1(\mathrm{n}=1)$ : Most of symptoms were present i.e. (100\%). Subgroup 2 and Subgroup 3 (n=0): 0 patients were belonged to this group.
III. In Stage $3(n=75)$ showing in Table 4.

Group 1 (n=64)

Hasta Padashiro Gulpha Trika Janu Uru Sandhishau Sarujam Shotham, Rujyate Atyartham, Utsahahani and Jadya were present in 97\% cases, i.e., followed by Agnidaurbalya (94\%).

Group 2 ( $\mathrm{n}=11)$

Subgroup $1(n=5)$

Most of symptoms were present in all cases, i.e., $100 \%$.

Subgroup $2(n=4)$

Most of symptoms were present in all cases, i.e., $100 \%$.

Subgroup $3(n=2)$

Most of symptoms were present in all cases, i.e., 100\%.

Comparison between Group 1 and Group 2

In Stage 3, "Z" test is applied and on comparison it was observed that between the all symptoms of Pravriddha Amavata Agnidaurbalya, Aruchi, Gauravam, Kukshaukathinatama Shulam, and Trit show significant result.

\section{Observation on objective criteria}

Out of 100 patients of Amavata the erythrocyte sedimentation rate was within normal limit in 11 cases, ESR was increased in 29 cases, i.e. $>20 \mathrm{~mm}$ in $1^{\text {st }} \mathrm{hr}$ and high ESR value, i.e., $>40 \mathrm{~mm}$ in $1^{\text {st }} \mathrm{hr}$ was observed in 60 cases (Table 5).

RA factor titer was higher in 86 cases and it was within normal limit in 14 cases (Table 6).

C-reactive protein value was higher in 91 cases and it was within normal limit in 9 cases (Table 7).

Table 8 shows that out of 35 registered cases $17 \%$ cases had the antiCCP value within normal range while $83 \%$ cases had the anti-CCP

Table 4: Assessment of Pravriddha Lakshana of Amavata in Stage $3(n=75)$ and comparison of symptoms between 2 groups

\begin{tabular}{|c|c|c|c|c|c|c|}
\hline \multirow[t]{2}{*}{ S. No. } & \multirow[t]{2}{*}{ Symptoms } & \multirow{2}{*}{$\begin{array}{l}\text { Group 1(n=64) } \\
\text { RA } \\
n=64(\%)\end{array}$} & \multicolumn{3}{|l|}{ Group $2(n=11)$} & \multirow{2}{*}{$\begin{array}{l}Z \text { value and } \\
p \text { value }\end{array}$} \\
\hline & & & $\begin{array}{l}\text { Subgroup } 1 \text { (SLE) } \\
\mathrm{n}=5(\%)\end{array}$ & $\begin{array}{l}\text { Subgroup } 2 \\
\text { (Re.A) } n=4(\%)\end{array}$ & $\begin{array}{l}\text { Subgroup } 3(A S) \\
n=2(\%)\end{array}$ & \\
\hline 2 & Rujyate Atyartham & $62(97)$ & $5(100)$ & $4(100)$ & $2(100)$ & $\mathrm{Z}=1.40, \mathrm{p}>0.05$ \\
\hline 4 & Agnidaurbalya & $60(94)$ & $5(100)$ & $4(100)$ & $2(100)$ & $\mathrm{Z}=2.02, \mathrm{p}<0.05$ \\
\hline 5 & Praseka & $26(41)$ & $2(40)$ & $2(50)$ & $0(0)$ & $\mathrm{Z}=0.317, \mathrm{p}>0.05$ \\
\hline 6 & Aruchi & $47(73)$ & $5(100)$ & $4(100)$ & $2(100)$ & $\mathrm{Z}=4.86, \mathrm{p}<0.01$ \\
\hline 7 & Gauravam & $40(53)$ & $5(100)$ & $4(100)$ & $1(50)$ & $\mathrm{Z}=3.56, \mathrm{p}<0.01$ \\
\hline 8 & Utsahahani & $62(97)$ & $5(100)$ & $4(100)$ & $2(100)$ & $Z=1.40, p>0.05$ \\
\hline 9 & Vairasya & $42(66)$ & $3(60)$ & $3(75)$ & $0(0)$ & $\mathrm{Z}=0.682, \mathrm{p}>0.05$ \\
\hline 10 & Daham & 57 (89) & $5(100)$ & $4(100)$ & $0(0)$ & $\mathrm{Z}=0.572, \mathrm{p}>0.05$ \\
\hline 11 & Bahumutratam & $34(53)$ & $3(60)$ & $1(25)$ & $2(100)$ & $\mathrm{Z}=0.123, \mathrm{p}>0.05$ \\
\hline 14 & Trit & $26(35)$ & $4(80)$ & $3(75)$ & $1(50)$ & $\mathrm{Z}=2.59, \mathrm{p}<0.01$ \\
\hline 15 & Chardi & 38 (59) & $5(100)$ & $2(50)$ & $2(100)$ & $\mathrm{Z}=1.75, \mathrm{p}>0.05$ \\
\hline 16 & Bhrama & $53(83)$ & $5(100)$ & $3(75)$ & $2(100)$ & $\mathrm{Z}=0.814, \mathrm{p}>0.05$ \\
\hline 17 & Murccha & $0(0)$ & $0(0)$ & $0(0)$ & $0(0)$ & 0 \\
\hline 18 & Hrid Graha & $16(25)$ & $3(60)$ & $1(25)$ & $2(100)$ & $\mathrm{Z}=1.88, \mathrm{p}>0.05$ \\
\hline 19 & Vidvibaddhatam & $53(83)$ & $3(60)$ & $3(75)$ & $1(50)$ & $\mathrm{Z}=1.24, \mathrm{p}>0.05$ \\
\hline 20 & Jadya & $62(97)$ & $5(100)$ & $4(100)$ & $2(100)$ & $\mathrm{Z}=1.40, \mathrm{p}>0.05$ \\
\hline 21 & Antrakujanam & $53(83)$ & $4(80)$ & $2(50)$ & $1(50)$ & $\mathrm{Z}=1.24, \mathrm{p}>0.05$ \\
\hline 22 & Anaha & $44(69)$ & $3(60)$ & $4(100)$ & $2(100)$ & $\mathrm{Z}=1.004, \mathrm{p}>0.05$ \\
\hline
\end{tabular}


value more than $25 \mathrm{U} / \mathrm{ml}$ which shows an positive result and helped in making diagnosis.

Higher value of ANA indicates patient may be suffering from any other autoimmune disease (Table 9).

Higher value of anti-dsDNA favors the presence of SLE (Table 10).

Out of 8 cases about $62 \%$ cases had the HLA B 27 positive result while $38 \%$ cases had the HLA B27 negative result. These patients were diagnosed as - 3 patients of Re.A with HLA B27 positive and 5 cases of A.S ( 2 cases with HLA B27 positive and 3 cases with HLA B27 negative) (Table 11)

\section{DISCUSSION}

Amavata results from the complex interactions between Vata, Kapha, Ama, environmental factors, and the immune system. Improper diet and lifestyle disturbs the leads to abnormal homeostasis of Doshas resulting into sluggish functions of Agni leading to development of Ama.

Ama combines with agitated Vata moves to Kaphasthanas and develops the disease Amavata.

A total of 100 registered cases who fulfilled the diagnostic criteria of Amavata (Samanya lakshana and Pravriddha lakshana) were classified into three stages based on duration, i.e., Stage 1: Duration of disease less than 6 months, Stage 2: Duration of disease from $>6$ months to 1 year, and Stage 3: Duration of disease more than 1 year. About 100 patients of Amavata were further divided into following groups based on the objective criteria that fulfilled the diagnosis of respective diseases, i.e., Group 1, 86 patients of Amavata were diagnosed as RA, 6 patients were diagnosed as SLE; 5 patients were diagnosed as Re.A and 3 patients were diagnosed as AS. It may be concluded that Amavata

Table 5: The ESR in diagnosed Amavata patients $(\mathrm{n}=100)$

\begin{tabular}{llccc}
\hline S. No. & ESR range in $\mathbf{~ m m} / \mathbf{1}^{\text {st }} \mathbf{h r}$ & $\mathbf{< 2 0}$ & $\mathbf{> 2 0}$ & $>\mathbf{4 0}$ \\
\hline 1 & Total number of cases & 11 & 29 & 60 \\
\hline
\end{tabular}

ESR: Erythrocyte sedimentation rate

Table 6: The RA factor titer in diagnosed Amavata patients $(n=100)$

\begin{tabular}{llll}
\hline S. No. & RA factor titer & Evaluation & $\begin{array}{l}\text { Total number of } \\
\text { individual (\%) }\end{array}$ \\
\hline 1 & $>20 \mathrm{IU} / \mathrm{ml}$ & Positive & $86(86)$ \\
2 & $<20 \mathrm{IU} / \mathrm{ml}$ & Negative & $14(14)$ \\
\hline
\end{tabular}

Table 7: The C-reactive protein value in diagnosed Amavata patients $(n=100)$

\begin{tabular}{llll}
\hline S. No. & C-reactive protein value & Evaluation & $\begin{array}{l}\text { Total number } \\
\text { of individual } \\
\mathbf{n = 1 0 0}(\%)\end{array}$ \\
\hline 1 & $>0.6 \mathrm{mg} / \mathrm{dl}$ & Positive & $91(91)$ \\
2 & $<0.6 \mathrm{mg} / \mathrm{dl}$ & Negative & $9(9)$ \\
\hline
\end{tabular}

Table 8: The anti CCP value in misdiagnosed patients Amavata as rheumatoid arthritis $(n=35)$

\begin{tabular}{llll}
\hline S. No. & Anti CCP & Evaluation & $\begin{array}{l}\text { Total number of individual } \\
\mathbf{n = 3 5}(\mathbf{\%})\end{array}$ \\
\hline 1 & $>25 \mathrm{U} / \mathrm{ml}$ & Positive & $29(83)$ \\
2 & $<25 \mathrm{U} / \mathrm{ml}$ & Negative & $6(17)$ \\
\hline \multicolumn{2}{l}{ CCP: Cyclic citrullinated peptide }
\end{tabular}

is a syndrome and may be correlated to arthropathies mentioned in modern medicine. Table 1 shows that $36 \%$ patients were of $25-$ 34 years age group followed by $28 \%$ patients were of $35-44$ years age group. It has mentioned that onset of the majority of the arthropathy were frequently diagnosed during the $2^{\text {nd }}$ and $4^{\text {th }}$ decades of life [5]. 86\% patients of Amavata were diagnosed as RA and out of these $84 \%$ patients were female which was almost similar to studies conducted by Al- Bishri et al. (78\% vs. $22 \%$, respectively) and Bajraktari et al. ( $76.8 \%$ vs. $23.2 \%$, respectively) [6].It may be due to hormonal factor and sex linked genes. Table 2 shows that $100 \%$ cases of diagnosed SLE were female. SLE is a chronic inflammatory disease that has a protean manifestation. More than $90 \%$ of cases are seen in women. SLE, an autoimmune disorder characterized by multisystem inflammation with the generation of autoantibodies [7].This study provides the base for research to innovate and select the drugs mentioned for Amavata management may be screened to invent the drugs for the better management of challenging arthropthies.

About $86 \%$ patients were of RA which has very similar pathogenesis of Amavata which is stated by Turnbagh theory. Turnbagh and coworkers suggested that a set of core microbiome is present in humans living in a certain habitat conditions. Variability among individuals could arise due to the host lifestyle, diet, health, immune system, and environment. In this theory, they described that RA is a multifactorial disease and requires interaction between genetic and environmental factors for predisposition. The presence of bacterial DNA of the gut residing commensals in synovium as well as dysbiosis of certain commensal bacteria in fecal samples of RA patients as compared to controls suggest a significant role of the gut flora in pathogenesis of RA [8]. This concept described in Ayurveda as erratic diet and lifestyle causes variability in gut due to hindered digestive power as a result disturbed Agni yields immature Rasa (Ama) in Amashaya . It is absorbed in the system and taken up by aggravated and vitiated Vata especially to the Kapha sthana mainly Amashaya, Sandhi, Uras, Kantha, etc., and causes genesis of symptom complex. This concept of Amavata pathogenesis may be proved scientifically by this theory.

Table 9: The antinuclear antibody assay in diagnosed Amavata patients ( $n=14)$ having negative result for $R A$ factor

\begin{tabular}{llll}
\hline S. No. & Antinuclear antibody & Evaluation & $\begin{array}{l}\text { Total } \\
\text { number }(\mathbf{n}=\mathbf{1 4})\end{array}$ \\
\hline 1 & $>1.4$ & Positive & 10 \\
2 & $<1$ & Negative & 4 \\
3 & $1-1.4$ & Equivocal & 0 \\
\hline
\end{tabular}

RA: Rheumatoid arthritis

Table 10: The anti dsDNA antibody test in diagnosed Amavato patients $(n=10)$ having ANA test positive

\begin{tabular}{llll}
\hline S. No. & Anti dsDNA (IU/ml) & Evaluation & $\begin{array}{l}\text { Total number of } \\
\text { individual (\%) }\end{array}$ \\
\hline 1 & $>55$ & Positive & $6(60)$ \\
2 & $<35$ & Negative & $4(40)$ \\
3 & $35-55$ & Equivocal & $0(0)$ \\
\hline \multicolumn{2}{l}{ ANA: Antinuclear antibody, dsDNA: Double stranded DNA }
\end{tabular}

Table 11: The HLA B27 genotyping result in diagnosed Amavata patients $(n=8)$ with 4 cases with ANA negative and 4 cases with anti dsDNA negative but ANA positive result

\begin{tabular}{lll}
\hline S. No. & HLA B27 & Total number of individual (\%) \\
\hline 1 & Positive & $5(62)$ \\
2 & Negative & $3(38)$ \\
\hline
\end{tabular}

HLA: Human leukocyte antigen, ANA: Antinuclear antibody, dsDNA: Double stranded DNA 


\section{CONCLUSION}

It may be concluded that Amavata may be correlated to RA, SLE, Re.A, and AS. This clinical study provides vital clue for the management of above arthritis from Ayurveda perspectives based on Amavata management principles. Further, it also helps to invent the newer therapeutic combination from the Amavata treatment principles to manage these challenging arthropathies.

\section{REFERENCES}

1. Sharma RK, Bhagwan D, Samhita C. Vata Vyadhi Chikitsa Adhyaya. Vol. V. Varanasi: Chaukambha Sanskrit Series Office; 2013.

2. Neera S, Kumar PP, Byadgi PS. Role of viruddhahara in the genesis of Amavata. Am J Pharm Health Res 2015;3(3):1-10.
3. Yadunandan U. Madhava Nidanam with 'Madhukosha' Commentary, Amvatanidanadhaya. Varanasi: Chaukhamba Publication; 2009.

4. Byadgi PS. Ayurveda Vikriti Vigyan and Roga Vigyan. Ch. 21. Varanasi, India: Chaukambha Publication; 2009. p. 206.

5. Longo DL, Faucy AS, Kasper DL, Hauser SL, Jameson J, Loscalzo J, et al. The spondyloarthritides. Harrison's Principles of Internal Medicine. $19^{\text {th }}$ ed., Vol. I. USA: McGraw-Hill Companies; 2016.

6. Kashefl S, Lee SM, Mallaysamy SR, Thunga PG. Demographic, clinical characteristics and drug prescription pattern in patients with rheumatoid arthritis in South Indian tertiary care hospital. Int J Pharm Pharm Sci 2016;8(8):251-7.

7. Keerthana PC, Anila KN. Carbamazepine induced SLE-a rare and serious ADR. Int J Pharm Pharm Sci 2017;9(1):319-20.

8. David L, Andres G, Joseph M, White B, Taneja V. The role of the gut in autoimmunity. Indian J Med Res 2013;5:732-43. 